\title{
Marketing and Brand Authenticity in Post COVID-19 Era
}

ISSN: 2637-7659

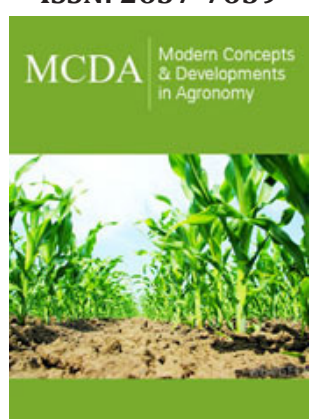

*Corresponding author: Petros Gkogkos, 1Green Box Publications SA, 10557 Athens, Greece

Submission: 狊 February 22, 2021

Published: 佔 March 11, 2021

Volume 8 - Issue 2

How to cite this article: Petros Gkogkos, Dimitris Skalkos. Marketing and Brand Authenticity in Post COVID-19 Era. Mod Concep Dev Agrono. 8(2). MCDA. 000683. 2021. DOI: 10.31031/MCDA.2021.08.000683

Copyright@ Petros Gkogkos. This article is distributed under the terms of the Creative Commons Attribution 4.0 International License, which permits unrestricted use and redistribution provided that the original author and source are credited.

\author{
Petros Gkogkos ${ }^{1 *}$ and Dimitris Skallkos ${ }^{2}$ \\ ${ }^{1}$ Green Box Publications SA, 10557 Athens, Greece
}

${ }^{2}$ Laboratory of Food Chemistry, Department of Chemistry, University of Ioannina 45110 Ioannina, Greece

\begin{abstract} era.

Keywords: Brand Authenticity; COVID-19; Food branding; Marketing; Agriculture
\end{abstract}

The deep existential nature of authenticity combined with the change towards green sustainability can transform the concept of brand authenticity, an inspiring tool for food industry and agricultural business in order to build a new brand image that will enable them to capitalize on the economic post pandemic

\section{Introduction}

Looking beyond the short term COVID-19 and quarantine current period, researchers picture the future of food and food industry with regards to health values, environmental sustainability and locality [1]. In that concept Brand Authenticity seems to be gaining a new importance and especiallyfor those brands and regions that represent a production model based on added value inherited [2]. In order to capitalize this upcoming bull market, adoption and change must be implemented, and it seems that some brands have already made major steps towards this [3].

In times of uncertainty, the factor of authenticity tends to become an essential human aspiration, making it a key issue in contemporary marketing and a major factor for brand success [4].

Authenticity describes a place and the factors behind the particular place (people, history, culture) that is genuine, unaltered and without hypocrisy [5], borrowing those terms from phenomenological and existential philosophy [6]. Regardless of the historical time or the geographical, technological, and social situation, people will always need place to refer to. We identify ourselves with place as integral part of what and who we are as human beings [7].

In the beginning of $21^{\text {st }}$ century, brand authenticity in the context of academic research remained inan archaic phase even though consumers' demand for authenticity has existed for hundreds of years [8]. Today one of modern marketing's central themes is the tension between authenticity and in- authenticity [9]. Four dimensions of authenticity have been identified, which are: continuity, originality, reliability, and naturalness [4]. They were identified by literature review and several studies with different consumers and brands, and by developing a scale for measuring the strength of consumers' perceivedbrand authenticity.

Relatively recent research found that brand authenticity is a critical determinant of impression in memory, lifestyle-congruence, and brand love [10]. In the world of international brands, a lack of authenticity has been observed, which stimulates even more consumers' desire for authentic experiences and genuine brands that undercovers the impact of heritage, of quality and labelling schemes on consumer-brand relationships [11].

In the field of health functional food products and other specialties, it has been proved that brand authenticity is an important antecedent for forming brand trust and brand relationship quality with consumers, suggesting that authenticity is an important factor in brand management of health functional food and other products [12].

By linking geographical origin and ecosystem services with food production European Union developed geographical indication schemes that aim to protect specific know how, 
authenticity and agro-environmental conditions [13], paving the way for a pan- European food brand that can increasetraditional food products competitiveness.

The exact same high value recognition of these products led to economically motivated product adulteration in many cases with a big number of reviews, that provide evaluation methods used for the determination of provenance and authenticity of these products [14]. This attention seems to implyimportant competitiveness that the concept of food brand authenticity may give to industries and foods.

\section{Brand authenticity during the lock-down period}

Now more than ever, because of the pandemic crisis and the uncertainty of our times consumers tendto reach out for authentic products and brands that can guarantee authenticity. A study on consumers shopping during the first two weeks of lockdown in Spain, showed that products with geographical indication, linked to quality assurance and food safety, increased their importance [15]. It was observed that $61.4 \%$ of consumers modified their buying behavior at the onset of the COVID-19 pandemic.

This crisis displays characteristics that differ from other economical downcycles and the first approaches show that despite the economical sovereignty consumers are willing to pay more for theirgroceries and other food related services [16]. At the same time, word of mouth has it that e-commerce is expanding. Social distancing is leading to a shift to online shopping among many consumers and online stores are experiencing enormous increases in turnover [16]. In addition to this, brands seem to engage in innovative initiatives such as the case of CK Mondavi wines, a winery that is now running virtual educational tastings for their Aloft and Dark Matter wine brands [17].

Brand Authenticity refers both to the product and the company [4]. Charles Taylor has pictured the impact of COVID-19 in advertising, citing that during the pandemic advertisement focused especially on corporate social responsibility coloring mostly the aspects of consumer safety, employee welfare, honoring first responders, donations to charity [17].

\section{Post covid era predictions}

The current global pandemic prompted many companies to step up and provide products and servicesurgently needed during the crisis and therefore expectations on companies are elevated because people have grown accustomed to visibility into companies' cultural practices and likely they will usesocial platforms to hold company leaders accountable for acting responsibly [18].

This new condition reveals the dynamics between consumers and brand age as well, since old brandstend to send the message that they have the "know how" in order to succeed, while on the other handyoung consumers might think that they represent an old and obsolete world [19]. On industry level, some point out that the crisis unfolded by COVID19 will provide the impetus to change industrial agriculture for a transition towards agroecologically based food systems [20], a production model applied in most premium and authentic brands which gives a new space of exploration into brand authenticity.

Production chains, which have lengthened as the result of globalization, will shorten again [21], while consumer trust in the food sector will increase over the course of the COVID-19 pandemic. As a new report from European Institute of Innovation and Technology has revealed, farmers are placed at thetop of the tree when it comes to trust in food producers.

\section{Conclusion}

This era should stimulate researchers to investigate changes in the relevant stages in consumer behavior, both with regards to (the pre-) buying (process) and with regards to use and the disposal of the products and services [16]. The momentum that is being built during those dark times of social life, will be capitalized in the long term especially from small and middle size agricultural business. They are equipped with the authenticity filters the new market era seems to be working with.

Even though brand authenticity is a relatively new term, the deep existential nature of authenticity combined with the turn towards green sustainability can provide industry, including food industry and agricultural business, a new brand image to build upon. It seems that the deeper modern societydeeps into the waters of cyber reality, the bigger the need for authentic experiences becomes. Futureresearchers might want to consider what might be more authentic and pragmatic than cultivating earthand producing food. Developing marketing techniques that communicate and ensure consumers aboutauthenticity and sustainability of a product, can be game changing for traditional industries.

\section{References}

1. Riefler P (2020) Local versus global food consumption: the role of brand authenticity. Journalof Consumer Marketing 37(3): 317-327.

2. Grayson K, Martinec R (2004) Consumer perceptions of iconicity and indexicality and their influence on assessments of authentic market offerings. Journal of Consumer Research 31(2): 296-312.

3. Taylor C (2020) How brands can successfully engage with consumers quarantined due to COVID-19.

4. Bruhn M, Schoenmüller V, Schäfer D, Heinrich D (2012) Brand authenticity: Towardsa deeper understanding of its conceptualization and measurement. Advances in Consumer Research 40: 569-577

5. Relph E (2016) Place and placelessness. Sage, London.

6. Seamon D, Sowers J (2008) Place and placelessness. Relph E(Ed.), Key texts in human geography, Sage, London, pp. 43-52.

7. Malpas J (1999) Place and experience: A philosophical topography. (1 $1^{\text {st }}$ edn), Routlegde, London, United Kingdom.

8. Brown S (2015) Marketing-the retro revolution. Sage Publications Ltd, California, USA.

9. Manthiou A, Kang J, Hyun S, Fu X (2018) The impact of brand authenticity on building brand love: An investigation of impression in memory and lifestyle-congruence. International Journal of Hospitality Management 75: 38-47.

10. Assiouras I, Liapati G, Kouletsis G, Koniordos M (2015) The impact of brand authenticity on brand attachment in the food industry. British Food Journal 117(2): 538-552. 
11. Lee J, Chung L (2019) Effects of perceived brand authenticity in health functional food consumers. British Food Journal 122(2): 617-634.

12. European Commission, EU quality food and drink Discover European food and drinks protected by geographical indication schemes.

13. Krajnc B, Bontempo L, Luis Araus J, Giovanetti M, Alegria C, et al. (2020) Selective methods to investigate authenticity and geographical origin of Mediterranean food products. Food Reviews International 37(8): 1-27.

14. Brugarolas M, Martínez Carrasco L, Rabadán A, Bernabéu R (2020) Innovation strategies of the spanish agri-food sector in response to the black swan COVID-19 pandemic. Foods 9(12): 1821.

15. Hoekstra J, Leeflang P (2020) Marketing in the era of COVID-19. Italian Journal of Marketing 2020(4): 249-260.

16. Taylor CR (2020b) Advertising and COVID-19. International Journal of Advertising 39(5): 587-589.
17. Yohn D (2020) Brand authenticity, employee experience and corporate citizenship priorities in the COVID-19 era and beyond. Strategy \& Leadership 48(5): 33-39.

18. Shabbir J, Suki N (2020) Impact of perceived brand age on consumerbased brand equity: Post-COVID-19 pandemic era. European Journal of Molecular \& Clinical Medicine 7(8): 1111- 1117.

19. Altieri MA, Nicholls C (2020) Agroecology and the emergence of a post COVID-19 agriculture. Agriculture and human values 37(3): 525-526.

20. Ginanneschi M (2020) The future of food after COVID-19 through the lens of anthropology. Journal of Agriculture, Food Systems, and Community Development 9(4): 1-3.

21. EIT FOOD (2021) Farmers chosen as most trusted group within the food sector by European consumers.

For possible submissions Click below:

Submit Article 